ISSN : 2722-7820 (Online)

Point of View Research Accounting and Auditing

https://journal.accountingpointofview.id/index.php/povraa

\title{
Several factors influence the willingness to Pay taxes
}

\author{
Isnaeni Ali †, Mursalim 2, Fadliah Nasaruddin 3
}

Universitas Muslim Indonesia, Urip Sumohardjo KM.5 Street, Panaikang, Makassar, 90231, South Sulawesi, Indonesia

\begin{tabular}{|c|c|}
\hline Submission Info : & Abstract \\
\hline $\begin{array}{r}\text { Editor : Syarifuddin } \\
\text { Received 16 July } 2020 \\
\text { Accepted 22 July } 2020 \\
\text { Available online 22 July } 2020\end{array}$ & $\begin{array}{l}\text { This study aims to analyze and examine the Factors Affecting the Will to } \\
\text { Pay Taxes at the West Makassar Pratama Tax Office. The independent } \\
\text { variable in this research is Tax Knowledge, Fiscus Services and Tax } \\
\text { Examination while the dependent variable is Tax Paying Will. The research }\end{array}$ \\
\hline $\begin{array}{r}\text { Keyword : } \\
\text { Taxation Knowledge } \\
\text { Fiscus Service } \\
\text { Tax Examination } \\
\text { Willingnes to Pay Taxes }\end{array}$ & $\begin{array}{l}\text { Regression analysis, with a total sample of } 100 \text { respondents. The results } \\
\text { showed that simultaneous and partial knowledge of taxation, tax services } \\
\text { and tax audits had a significant positive effect on the willingness to pay } \\
\text { taxes at the West Makassar Pratama Tax Office. }\end{array}$ \\
\hline$\overline{\text { Email : }}$ & \\
\hline $\begin{array}{r}\text { isnaeniali80@gmail.com } \\
\text { mursalim@umi.ac.id } \\
\text { fadliah.nasaruddin@umi.ac.id }\end{array}$ & $\begin{array}{l}(c) \text { EY } \\
\text { This is an open access article under the CC BY } 4.0 \text { International License } \\
\text { (C) Point of View Research Accounting and Auditing (2020) }\end{array}$ \\
\hline
\end{tabular}

\section{Introduction}

In the context of increasing tax revenues, tax intensification and intensification efforts are steps that have been launched by the Directorate General of Taxes by expanding tax subjects and objects or by capturing new taxpayers (Pelu et al., 2020). On the other hand, such a dynamic business development requires government reach in terms of taxation and the systems and rules that support it. Although the safety net for taxpayers (in the form of Taxpayer Identification Number) in order to carry out their tax obligations has been installed, especially for the increasingly dynamic business, but the efforts of entrepreneurs or taxpayers are still free from the taxation. Actually there are still many potential taxpayers who have not been registered as actual taxpayers. Disobedience in paying taxes does not only occur at the level of entrepreneurs but it is common knowledge that taxpayers tend to be dishonest in providing information on income and wealth owned (Amran, 2018). The reason for the lack of will is the principle of taxation, which is the result of tax collection that cannot be directly enjoyed by taxpayers (Hardiningsih \& Yulianawati, 2011).

Amran (2018) explains that various issues affecting taxpayer awareness are grouped into two, namely, internal factors such as tax institutions, including tax regulations which may still be considered complicated, not yet simple in the support of taxpayer information technology and human resource professionalism. External 
factors can come from self taxpayers and the environment that is not good so that taxpayers do not comply. The research of Handayani et al., (2012) shows that of the four variables studied namely, awareness of paying taxes, knowledge and understanding of taxes, a good perception of the effectiveness of the taxation system and a level of confidence in the government and legal system, partially only a variable of knowledge and understanding of taxation has an influence on the willingness to pay taxes while the other three variables have no effect on the willingness to pay taxes. This means that in addition to trust, law enforcement and the taxation system, taxpayers tend to avoid taxes, on the grounds of not knowing and understanding.

Research Hardiningsih \& Yulianawati (2011) shows that awareness of paying taxes has an effect on the willingness to pay taxes, knowledge of tax regulations has no effect on willingness to pay taxes, understanding tax regulations has no effect and perceptions of the effectiveness of the tax system also have no effect. while the quality of service affects the ability to pay taxes. Knowledge arises when a person uses his intellect to recognize certain objects or events that have never been seen or felt before (Utami \& Soerono, 2012). Taxpayers who do not understand tax regulations clearly tend to be disobedient taxpayers. It is clear that the more understanding of taxpayers with tax regulations, the more understanding of taxpayers of sanctions will be received if they neglect their tax obligations. The more you know and understand the taxpayers regarding tax regulations, the more you know and understand the taxpayers about the sanctions that will be received if you neglect their tax obligations. This will certainly encourage every compliant taxpayer to carry out their obligations properly. Knowledge and understanding of PTKP, PKP and tax rates. Knowledge and understanding of the applicable tax rates can encourage taxpayers to be able to calculate their own tax obligations correctly (Hamzah et al., 2018). The phenomenon of lack of knowledge and understanding possessed by taxpayers is the main reason why taxpayers do not obediently pay taxes even to the point of breaking the law. This phenomenon clearly illustrates that taxpayers in every region including West Makassar Primary Tax Office have a tendency to use the services of a tax consultant

According to Supadmi (2009), a service can be said to be good if the business is run in accordance with what is expected. Quality services are services that can provide satisfaction to customers and remain within the limits of meeting service standards that can be accounted for and must be carried out continuously. Quality services provided to taxpayers include: First, the tax administration procedure is made simple so that it is easily understood by all taxpayers, NPWP registration, the existence of a tax information system and a tax administration system, so that the service system for taxpayers is increasingly tangible. Second, tax officers or Fiscus are expected to have competence in knowledge, experience and humanism skills by making adjustments to local indegenius elements, or norms that can support the satisfaction of taxation services.

The antipathy attitude of some taxpayers towards the attitude of service officers who are considered less professional in providing maximum services to taxpayers occurs because of events at the service counters. Although the problem of taxpayer satisfaction is difficult to generalize, because of a dichotomy in the perception of taxpayers. In terms of taxation policies, tax administration and tax legislation, the service of the bank officer where the payment is obliged to serve and provide an explanation to the taxpayer in a friendly manner so that taxpayers really understand as expected or desired (Winarsih, 2018). The Primary Tax Office provides an expansion of integrated service points (TPT), with this expansion it can improve taxpayer services by establishing a service for taxpayers without having to go to each section (Hardiningsih \& Yulianawati, 2011).

Tax audits are carried out to taxpayers if there are attitudes or actions that violate taxation rules. Such attitudes such as fraud, or tax evasion. A tax check is conducted to arouse taxpayer compliance, in addition to providing a deterrent effect on naughty taxpayers so as not to repeat the same actions in the future. In addition, taxpayers often deliberately cheat tax payments that should be done, therefore to test compliance it also needs to be examined. If the results of the examination found a formal violation, the taxpayer will be subject to tax administration sanctions that can be in the form of fines or interest that will be collected by the tax authorities with a tax bill. Miniawati et al., (2018) said that tax audits were carried out because taxpayers were suspected of committing fraud and avoiding actual taxation. Research Miniawati et al., (2018) found that tax audits have an effect on tax revenue. Monica \& Andi (2019) who stated that tax audits had a negative and significant effect on the effectiveness of tax revenues in Surakarta (KPP).

Some of the research that has been described is different from this research instrument from object factors, variable composition, theories used, and time taken, as well as the samples needed. For example, the authors 
chose the dependent variable namely the willingness to pay taxes, as well as the variables predicted to have a negative effect, namely the tax audit with the willingness to pay taxes. Someone who is willing to pay taxes has many considerations, one of which is based on economic considerations of the expected cost-benefits. Rational theory assumes that every human being is basically rational by always considering the principles of efficiency and effectiveness in carrying out every action. This theory was pioneered by Alfrad Marshall (18421924), Keynes (1924) states that humans always tend to maximize their rationality, always tend to calculate the value of something (utility) to be exchanged. This theory is also supported by Adam Smith's opinion that human behavior is guided by instrumental rationality related to self-interest and drawn by the prospect of reward. Rational actions are related to results. Rationality says, if we want to achieve Y, do X. Basically conditional rationality and future-oriented (Elster, 1989). In connection with the willingness to pay taxes, rationality which is the foundation in economic theory in producing decisions whether to obey tax rules or not.

The moral theory of tax according to Frey (1999) is the intrinsic motivation of individuals to act, which is based on values that are influenced by cultural norms. Moral principles or values that a person believes in paying taxes. Several factors affect tax morals such as: the perception of honesty, the attitude of helping or serving from tax officials, trust in government agencies, appreciation or respect from tax officials (respect), and other individual traits. This theory, with the approach of community psychology, holds that between the community and the government there is an implicit contract, in which the community realizes that they have rights and obligations. Virtue of citizens will emerge as a result of the rights of collective participation of the people. Doerrenberg \& Peichl (2018), found that participants in reciprocal treatment had significantly higher tax morals than those who were in social norm education. This means what to pay taxes while Tax Evasion treatment is very common. In Peichel's experiment above, they might be more obedient if (they believe that) most taxpayers pay taxes honestly. This is also reinforced by Paetzold \& Winner (2016) who explain that reciprocity in this context means that the motivation to pay depends on the service and quality of the state and government that citizens receive in return for their tax payments (Frey, 2003; Akdede et al. , 2016; Luttmer \& Singhal, 2014; Dwenger et al., 2016).

Rational expectation theory explains that taxpayers will only obey tax rules if there is a high probability that they will be examined and if the tax penalties are high. The evolution of research on tax behavior begins with the assumption of the classic model of tax evasion developed by Allingham \& Sandmo (1972). However, auditing policies and tax penalties sometimes have contradictory effects as expected (Holler et al., 2008). In addition, there may be variables other than rational economic variables (such as audit threats and fines) ethics, the level of trust in the legal and taxation system, and religiosity that affect tax behavior (Holler et al., 2008). Hanno \& Violette (1996) states that the decision to obey or disobey tax rules is a cognitive behavior that is under individual control. In making a tax compliance decision, taxpayers base their attitudes on compliance that develops over time through the acquisition of beliefs about the outcomes (compliance) and the evaluation of those outcomes.

Several studies have shown that increasing the likelihood of high tax audits and fines will increase tax compliance (Witte \& Woodbury 1985; Beck et al., 1991). Tax compliance will decrease if taxpayers perceive tax audits to be small because they believe that they will continue to commit fraud. The reason for using the theory used in this study is that the purpose of the audit is to test the fulfillment of taxpayers' tax obligations (compliance), and other objectives in order to carry out the provisions of tax legislation. Some theories that have been described give represent the selection of the variables studied, with some assumptions that first, how obliged to be able to carry out its obligations if he himself does not know what and how about taxation. Second, the audited taxpayer will delay his tax payment, the time interval from the inspection, will take time and lead to rejection of the issued SKP. Third, based on various studies that the compulsory willing to pay taxes must be guarded so that this will become a tradition of good citizenship, on the principle of causality, as well as the relationship between taxpayers and the government.

Knowledge of taxes is very important to foster compliance. The knowledge of taxpayers about good tax will be able to minimize the existence of tax evation (Witono, 2008, Hamzah et al., 2018). With the knowledge of taxation will help taxpayer compliance in paying taxes, so the level of compliance will increase. Taxpayers who are knowledgeable about tax, will self-consciously be obedient to pay taxes. They already know how the flow of tax revenue will run, until finally the benefits of paying the tax are felt. A taxpayer will obey pay taxes 
if the taxpayer has knowledge of taxation well. If the taxpayer knows the tax regulations, then the taxpayer will obey his tax obligations and will increase taxpayer compliance. The important thing of tax knowledge that must be the main focus is the process of changing attitudes from not knowing to knowing, and the behavior of a taxpayer or group of taxpayers in an effort to mature humans through teaching and training efforts. Knowledge of tax regulations in the new taxation system, taxpayers are given the confidence to carry out national cooperation through the system of calculating, calculating, paying, self-reported tax payable. With this system it is expected that taxpayers will know the function of tax payments. It is hoped that this system of justice can be realized. Fair means the taxpayer calculates according to the taxation provisions and the government knows to use all these according to the needs in order to develop the country.

Fiscus services can be interpreted as a way for tax officers to help take care of or prepare all the needs needed by Jatmiko taxpayers (2006). Nugroho \& Zulaikha (2012) quality services are services that can provide satisfaction to customers and remain within the limits of meeting service standards that can be accounted for and carried out continuously. Demands of service that are easy, fast, cheap and accurate are the people's expectations to carry out obligations the taxation. Fiscus services are very influential on taxpayers in paying their taxes. Therefore, it is demanded to provide friendly, fair and decisive services at all times to taxpayers and can accumulate public awareness about the responsibility of paying taxes. Fikriningrum (2012), Fadhilatunisa, (2020) explained that the ability of the tax authorities to interact well with taxpayers is the basis for the tax authorities to serve taxpayers so that they are expected to increase the taxpayer's willingness to pay taxes.

Satisfaction of taxpayers regarding fiscal services is formed by the dimensions of the quality of human resources (HR), tax provisions and tax information systems. Satisfaction of taxpayers on the quality of services provided by the tax authorities usually gives a positive response in the form of compliance with tax payments. If the tax provisions are made simple and easily understood by taxpayers, the tax authorities on the rights and obligations to taxpayers can be carried out effectively and efficiently. The new paradigm with a public administration approach explains that excellent tax service is a public service that requires the tax authorities to place taxpayers as customers who must be served as well as possible, like customers in business organizations. The purpose of this service is to maintain the satisfaction of taxpayers who later are expected to be able to increase the compliance of taxpayers in meeting their tax obligations. This description explains the importance of service quality for taxpayers is an important factor for the Tax Office to increase the willingness to pay taxes on taxpayers so that state revenue through the tax sector can be more. Providing good service to taxpayers, taxpayers will always fulfill their obligations to pay taxes because by providing good service to taxpayers, taxpayers will feel happy and feel facilitated and assisted in settling their tax obligations. This is certainly not separated from the vital role carried by each tax official.

Tax officers are required to be able to serve each Taxpayer well, courtesy, have respect for taxpayers as customers, and have expertise and knowledge in the field of taxation which will certainly support the quality of service from tax officers to taxpayers. In addition, equipment owned by the tax office is of course also needed, such as communication equipment, computers, good waiting rooms, queue numbers, and other supporting equipment. The services provided by the tax authorities during the taxation process are related to the attitude of the taxpayer. The taxation process involves the tax authorities and the taxpayer makes the services provided by the tax authorities contribute to the attitude of the taxpayer to follow the taxation process. The better the tax authorities, the taxpayers will have a positive attitude towards the taxation process. But if the tax authorities are not good, it will make taxpayers reluctant to pay taxes according to applicable regulations.

Article (1) Law No.16 of 2000 provides an understanding of the examination. "Examination is a series of activities to search, collect, and process data / or other information to test compliance with the fulfillment of tax obligations and for other purposes in order to implement the provisions of the legislation". According to Devano \& Rahayu (2006), to carry out law enforcement efforts, one of which is through tax audit measures, it is absolutely necessary to have tax audit personnel in adequate quantity and quality. Meanwhile, to get quality assurance on the results of the inspection work in addition to the required quantity and adequate quality also requires inspection procedures, as well as norms and rules governing a tax examiner. The purpose of the examination is to test compliance with the fulfillment of tax obligations and in order to carry out the provisions of tax legislation. Rahayu (2010), Su'un \& Ahmad (2020) argued that the tax audit is an oversight of the implementation of the self-assessment system carried out by taxpayers, must adhere to the tax laws. Some of 
the definitions explained explain that the tax audit is a series of activities to search, collect, process data and or other information to test compliance with taxation obligations in the context of implementing the provisions of tax legislation. Rahayu (2010) states that the audit will run smoothly if it is supported by factors that influence the implementation of tax audits such as the existence of information technology support, the amount of human resources and the quality of resources.

The concept of willingness to pay taxes is developed through two sub concepts, namely, the concept of willingness to pay and the concept of taxation. Willingness to pay tax is a value where someone is willing to pay, sacrifice or exchange something to get goods or services. While the second is the concept of tax. Willingness to pay taxes is influenced by several factors, namely the condition of a country's tax administration system, service to taxpayers, tax law enforcement, and tax rates (Devano \& Rahayu, 2006). The willingness to pay taxes is influenced by tax knowledge, perceptions of tax sanctions, public awareness of paying taxes, perceptions of tax officials, and perceptions of the ease of implementing the tax system (Setyonugroho, 2012). Willingness to pay taxes can be interpreted as a value that is willing to be given by someone or determined by the regulations used to finance public spending by the State without receiving direct reciprocity services. According to Devano \& Rahayu (2006) Willingness to pay taxes is influenced by several aspects, namely the condition of a country's tax administration system, services to taxpayers, law enforcement and tax rates.

In rational theory explained that taxpayers who want to pay their taxes are influenced by economic considerations. This also means that taxpayers also take into account the profit and loss of spending money as part of their tax obligations. In another theory it is also explained that compulsory is also influenced by intrinsic motivation as expressed in the tax morale theory by Frey (1999). This also means that taxpayers want the honesty of all parties related to tax payments. This attitude or perception is supported by empirical facts that there are still many taxpayers who have not done law enforcement fairly, thus affecting the behavior of taxpayers in paying their taxes. This theory was pioneered by for example Peichl (2017), in an experiment conducted on taxpayers in the UK. The problem faced by taxpayers in the West Makassar KPP working area is their lack of knowledge of tax regulations, and the functions of tax collection in the community. It is this lack of knowledge that causes many taxpayers to tend to allow their tax obligations. This is supported by research Riyanti (2017), who found that tax knowledge has a partial effect on taxpayer compliance. In other studies such as Hardiningsih \& Yulianawati (2011), Nugroho \& Zulaikha (2012), Murdiningtyas (2016), Setyorini (2016) suggested that the lack of taxpayer knowledge, which causes a lack of willingness to pay taxes.

According to Devano \& Rahayu (2006), Heryanto et al., (2020) Law enforcement efforts for tax violators will be carried out by inspection. Tax audits are carried out in an effort to improve taxpayer compliance. Research conducted by Sucandra \& Supadmi (2016), found that tax audits have a positive and significant effect on tax compliance. However Napitupulu (2005) found that the frequency of tax audits negatively affected taxpayer compliance. Monica \& Arisman (2018) in their research found that tax audits have a negative effect on tax revenue.

Factually, the willingness of taxpayers to pay taxes is a characteristic of taxpayer compliance and awareness. The difficulty of achieving a reasonable level of taxpayer compliance, in accordance with the great potential of the Indonesian people, is evidence that it is increasingly difficult for us to inject voluntary space for taxpayer awareness. a lot of research actually goes through discourse on obedience and awareness. Until now there has been no generalization between the definition of compliance and taxpayer awareness. This difficulty illustrates that the obligation to pay taxes is because he is obedient or conscious ?. The theory of tax awareness contains an element of compliance, and compliance also contains an element of awareness, as well as the willingness to pay taxes whether driven by both. Although this research is not focused on the philosophical aspects of awareness and compliance. Many studies always make compliance as a construction ending in modeling methodologically, as well as awareness, there are also studies that make awareness as an ending. One important variable in tax research is tax knowledge. This variable has been studied for more than half a century, and is always repeated. This indicates that tax knowledge for taxpayers is very important. The basic question that is built here is how we want to pay taxes, if we don't even know the amount, the place to pay is also not certain we know, let alone the conditions. Conversely, if this knowledge belongs to the taxpayer, it will automatically encourage taxpayers to pay their taxes. some of the results of research in the previous analysis provide gaps or open space for re-research. 
H1: Knowledge of taxation has a positive and significant effect on the willingness to pay taxes

Measurement of the level of satisfaction of taxpayers is the quality of service that is the comparison between the expectations of taxpayers for the services that should be received with the services actually received by them. Basalamah et al., (2016), showed the existence of factors that distinguish between public and private services. For Tax Office employees, service is important because it is already part of the Ministry of Finance's Organizational Culture. For public services, the five things that can be sources of service user expectations are prior experience, talk from the mouth they hear, explicit and implicit communication conducted by the public service provider unit and the personal needs of each public service user. Unfortunately the quality of service is not as easy to measure as the quality of an item. Therefore service quality is usually measured using the views of the service users themselves, which are often done by conducting surveys of service users. Fidiana's view (2014) explains that If Belkaoui (2004) tends to use economic indicators and moral aspects, Feld \& Frey (2002) approaches tax non-compliance from a psychological point of view with survey methods in 24 regional tax authorities in Switzerland for 25 years, from years 1970 to 1995. Feld \& Frey (2001) developed a two-sided study that highlighted the side of the tax authority (collector) and taxpayer as well. The results of this study indicate that the willingness to pay taxes is motivated by the tax authorities. This is also supported by various theoretical studies, both marketing and management, that if service is satisfying, people will be happy, and encourage them to pay taxes.

H2: Fiscus services have a positive and significant effect on the willingness to pay taxes

To improve taxpayer compliance in paying taxes, the step taken by the Directorate General of Taxation is to increase audits. The policy of increasing tax audits by the Directorate General of Taxes has the effect of increasing the number of tax auditors, increasing the burden of completing the per-examiner's Tax Inspection Report and increasing the frequency of audits. Bearing this in mind, research related to tax audits is interesting. Bagianto \& Yuniati's research (2018) found that the results of the path analysis prove that the tax audit has a significant effect on the effectiveness of receiving corporate income tax. Tax audits and taxpayer compliance have insignificant effect on revenue effectiveness. This is different from the findings of Iqbal \& Sholihin (2019) who found that the behavior of taxpayer compliance is at a higher level when the authority implements a taxation system in the form of a powerful rather than a trustful form and when the taxpayer experiences a tax audit in one previous period.

H3: The tax audit has a significant negative effect on the willingness to pay taxes

\section{Research Method}

The approach used in this research is quantitative research. Namely research methods that emphasize the phenomena that are objective and are used to examine populations or certain samples (Sugiyono, 2010). This research was conducted at the West Makassar KPP. To get the information needed in this study, the authors used the Questionnaire technique, which is a technique of collecting data through a list of questions in writing to respondents with the intention of obtaining accurate and valid data. The population in this study was the taxpayers who followed the Tax amnesty of 59,812 in the West Makassar Primary Tax Office. The sample in this study was determined based on the Slovin approach in order to obtain the number of samples as formulated based on the Slovin approach as follows:

$\mathrm{n}=\mathrm{N} /(1+\mathrm{N} .(\mathrm{e}) 2)$

The number of samples is calculated as follows:

$\mathrm{n}=59.812 /(1+200) 2)$

$\mathrm{n}=59.812 /(1+59.812 .(10 \%) 2)$

$\mathrm{n}=59.812 /(1+59.812 .(0,1) 2)$

$\mathrm{n}=59.812 /(1+59.812(0,01)$

$\mathrm{n}=59.812 / 599.12$

$\mathrm{n}=99,83$

rounded up to 100 respondents. 
The mathematical equation of multiple linear regression, if applied in the study is as follows:

$$
\mathrm{Y}=\mathrm{a}+\mathrm{b} 1 \mathrm{X} 1+\mathrm{b} 2 \mathrm{X} 2+\mathrm{b} 3 \mathrm{X} 3+\mathrm{e}
$$

Description :

$$
\begin{array}{ll}
\mathrm{Y} & =\text { Willingness to pay taxes } \\
\mathrm{a} & =\text { constant } \\
\mathrm{b} 1-\mathrm{b} 2 & =\text { Parameter (regression coefficient) } \\
\mathrm{X} 1 & =\text { Taxation Knowledge } \\
\mathrm{X} 2 & =\text { Fiscus Service } \\
\mathrm{X} 3 & =\text { Tax audits } \\
\mathrm{e} & =\text { Interference Variable (standard error) }
\end{array}
$$

\section{Result and Discussion}

\section{Result}

After conducting research, it is known that mandatory based on the dominant business sectors include the Provision of Accommodation and Provision of Drinking Drinking 40 WP, 10 WP warehousing services, 10 WP health and social services, Wholesale and Retail Trade, Repair and Maintenance of Car and Motorcycle 8

\begin{tabular}{|c|c|c|c|}
\hline No & Sector & $\begin{array}{c}\text { Total } \\
\text { Taxpayer }\end{array}$ & $\%$ \\
\hline 1 & Construction & 5 & 5,0 \\
\hline 2 & Wholesale and retail trade, repair and maintenance of cars and motorbikes & 8 & 8,0 \\
\hline 3 & Professional, Scientific and Technical Services & 5 & 5,0 \\
\hline 4 & Provision of Accommodation and Provision of Drinking Food & 40 & 40 \\
\hline 5 & Rental Services, Employment, Travel Agencies and Other Business Supports & 5 & 5,0 \\
\hline 6 & Transportation and Warehousing & 10 & 10 \\
\hline 7 & Information and Communication & 5 & 5,0 \\
\hline 8 & Processing industry & 8 & 8,0 \\
\hline 9 & Health Services and Social Activities & 10 & 10 \\
\hline \multirow[t]{2}{*}{10} & Other sectors include PP-23 & 4 & 4,0 \\
\hline & Total & 100 & 100 \\
\hline
\end{tabular}
WP, and the remaining 5 and 4 WP respectively (see table 1). Table 2 shows all the research variables have a Cronbach Alpha value greater than the standard value of 0.60 so that the question items in this study can be said to be relative. The results of reliability testing of all question items obtained Cronbach Alpha values greater than 0.6 so that it can be concluded that all items of this research question have met the reliability requirements or in other words that this questionnaire is reliable as an instrument of research. All variables have $r$ count greater than $r$ table that is 0.1654 , so the question items in this study can be said to be valid.

Table 1. Respondents by Business sector

Source: Data processed, (2020)

Table 2. Reliability Test Results

\begin{tabular}{lcc}
\multicolumn{1}{c}{ Variable } & Cronbach Alpha value & Cronbach Alpha standards \\
\hline X1. Taxation Knowledge & 0,753 & 0,60 \\
X2. Tax Fiscus Services & 0,784 & \\
X3. Tax audits & 0,682 & \\
Y. Will Pay Tax & 0,722 & \\
\hline
\end{tabular}

Source: Data processed, (2020) 
Table 3. Analysis of Multiple Linear Regretions

\begin{tabular}{|c|c|c|c|c|c|}
\hline \multirow[b]{3}{*}{ Model } & \multicolumn{3}{|c|}{ Coefficientsa } & \multirow[b]{3}{*}{$\mathrm{t}$} & \multirow[b]{3}{*}{ Sig. } \\
\hline & \multicolumn{2}{|c|}{ Unstandardized Coefficients } & \multirow{2}{*}{$\begin{array}{c}\text { Standardized } \\
\text { Coefficients } \\
\text { Beta }\end{array}$} & & \\
\hline & $\mathrm{B}$ & Std. Error & & & \\
\hline 1 (Constant) & .115 & .326 & & .353 & .725 \\
\hline Taxation Knowledge & .442 & .060 & .484 & 7.300 & .000 \\
\hline Tax Fiscus Services & .208 & .075 & .199 & 2.773 & .007 \\
\hline Tax audits & .360 & .064 & .380 & 5.579 & .000 \\
\hline $\mathrm{R}=801$ & \multicolumn{2}{|c|}{ F Count $=57.186$} & & & \\
\hline $\mathrm{R}_{2}=641$ & \multicolumn{2}{|c|}{ Sig $=0,000$} & & & \\
\hline
\end{tabular}

Based on table 5, the regression equation can be seen as follows:

$\mathrm{Y}=0.115+0,442 \mathrm{X} 1+0,208 \mathrm{X} 2+0,360 \mathrm{X} 3$

A constant value, namely bo $=0.115$, means that, if the tax knowledge variable $(\mathrm{X} 1)$, the fiscal service variable, (X2), and the Tax Examination variable (X3) do not change, the willingness to pay tax is 0.115 .

Regression coefficient Variable Knowledge taxation (X1) of 0.442 , this means that with tax knowledge possessed by taxpayers will increase the willingness of taxpayers to pay taxes. where every increase in tax knowledge, will increase the willingness to pay taxes, assuming the variables X2 and X3 are constant. Regression coefficient of the fiscal services variable, (X2) is 0.208 , this means that by increasing good fiscal services, it will increase the willingness to pay taxes assuming Variables X1 and X3 are constant. Regression coefficient variable Tax Examination, (X3) of 0.360, this means that with an increase in tax audits will increase the willingness to pay taxes, assuming Variables $\mathrm{X} 1$ and $\mathrm{X} 2$ are constant. The magnitude of the correlation coefficient $(\mathrm{R})$ is 0.801 , this shows that the magnitude of the relationship between the independent variables $\mathrm{X} 1, \mathrm{X} 2$, and $\mathrm{X} 3$, with the Dependent Variable (Y) that is the willingness to pay taxes of 0.801 . This means that the magnitude of the effect of independent variables on the dependent variable is 80.1.

F Test (Simultaneous Test), this test is intended to find out how the independent variables (consisting of tax knowledge, tax authorities, and Tax Examination simultaneously (together) affect the willingness to pay taxes at the Tax Office Pratama Makassar Barat. In the regression table obtained F-count $=57.186>$ Ftable $=3.09$, and has a significance level of 0,000 . Because the probability of 0,000 is much smaller than 0.05 , it can be said that the regression model that has been used can increase the willingness to pay taxes in, or it can be said that the variable tax knowledge, tax authorities, and tax audits, together affect the willingness to pay. tax at KPP Pratama West Makassar.

T test (Partial Test), to determine the effect partially from each of the independent variables Tax knowledge, Tax authorities, and Tax Examination, to the willingness to pay taxes at the West Makassar Pratama Tax Service Office, the following will be explained as follows:

Results of research testing the influence of Tax Knowledge on Tax willingness to show the value of $t$ arithmetic $=5,598>\mathrm{t}$ table $=1,660$ with a significance level of 0,000, smaller when compared with the level of $\alpha=5 \%$. This result shows that statistically, there is an influence of tax knowledge variable on the willingness to pay taxes. Thus the first hypothesis which states that tax knowledge has a positive and significant effect on the willingness of taxpayers to pay taxes at the West Makassar Pratama Tax Office is proven (H1 accepted).

Results found that the tax authorities affect the willingness to pay taxes at the West Makassar Primary Tax Service Office with a value of $\mathrm{t}$ arithmetic $=2.777>\mathrm{t}$-table $=1.660$ with a significance level of 0.007 smaller when compared with the level of $\alpha=5 \%$. These results indicate that statistically the Fiscus Service has an effect on the willingness to pay taxes. Thus the second hypothesis stating that the Tax Fiscus Service has a significant positive effect on the willingness to pay taxes at the West Makassar Pratama Tax Service Office is proven (H2 accepted).

The findings of the study, found that the value of $t$ count $=5,579>t$ table $=1,660$, with a significance level of 0,000 , smaller than the level of $\alpha=5 \%$. These results indicate that statistically the tax audit affects the willingness to pay taxes. Thus the third hypothesis which states that tax audits affect the willingness to pay taxes at the West Makassar Primary Tax Service Office, is proven (H3 accepted). 


\section{Discussion}

\section{Effect of Tax Knowledge on Tax Paying Will}

Based on the results of the study found that tax knowledge has a positive and significant effect on the willingness to pay taxes at the West Makassar Pratama Tax Office. This means that with taxation knowledge, taxpayers have the spirit to build awareness in paying taxes. This indicates that tax knowledge as tax information can be used by taxpayers as a basis for acting, making decisions, and for taking certain directions or strategies with respect to the implementation of their rights and obligations in the field of taxation.

In connection with the willingness to pay taxes, rationality which is the foundation in economic theory in producing decisions whether to obey tax rules or not. Tax knowledge in this study was tested to find out how much knowledge of taxpayers about the general provisions of taxation in this case registering to get NPWP, because there is an individual awareness that the state requires individuals who try and produce must register themselves, filling in the SPT knowing that tax as a civic obligation, until the rules on tax sanctions, to pay the tax payable. If the taxpayer has good tax knowledge, a positive perception of the tax will emerge and will foster motivation to the taxpayer.

In the perspective of tax morale theory, with the knowledge of taxpayers on taxation aspects, this is a substance in the relationship between state social contracts with the community (Dahlan (2018). Doerrenberg \& Peichl (2018), in an experiment about taxpayers who obey in fulfilling their obligations found that participants in reciprocal treatment had significantly higher tax morals than those in educating social norms, meaning what to pay for taxes while Tax Evasion treatment was very common. This finding of Doerrenberg \& Peichl (2018) also had fatal consequences for consistency of taxpayer knowledge about tax.

Based on the results of this study and associated with respondents' answers about indicators that make tax knowledge have a positive and significant effect on the willingness to pay taxes, among others, because it is driven by the Knowledge and Understanding of Taxation of taxpayers about the desire to register, and at the same time knowing what the tax is for get paid. Respondents' answers indicate that taxpayers in the study clearly knew that if a person is earning, he must register himself as a taxpayer. When this knowledge is implemented, the taxpayer will automatically have the next knowledge, which is why I have to pay taxes. With the knowledge of taxpayers about good tax will be able to reduce the opportunity to turn away from the consequences of their knowledge, which is to fight against their knowledge (Asrul et al., 2018). Knowledge of taxation becomes difficult for taxpayers, in fulfilling their responsibilities, this is also because taxation rules change very quickly, and many people don't know.

The next indicator is the taxpayer's knowledge of his understanding of tax sanctions. The questionnaire's answer indicated that taxpayers at West Makassar Primary Tax Office were statistically knowledgeable about tax sanctions, and therefore they could find out how the tax planning strategy was, although this way by many researchers was an entry point for resistance to Ockey taxpayer compliance (2018). The responses of respondents have a good average responsive category.

The third indicator in this variable is Knowledge and understanding of PKP, PTKP and tariffs. Based on the results of respondents' tabulations on this indicator, it can be said that what drives taxpayers in West Makassar Primary Tax Office pays taxes because they are influenced by knowledge of PKP, PTKP and tax rates. This means that if they do not know about this, it will be difficult to realize the willingness to pay taxes. This is reinforced by Rahayu's statement (2010), that taxpayers must have, among others, Knowledge of General Provisions and Tax Procedures, Taxation System in Indonesia, and Taxation Functions.

Understanding taxpayers for taxation regulations is a way for taxpayers to understand existing taxation regulations. Taxpayers who do not understand tax regulations clearly tend to be disobedient taxpayers. It is clear that the more understanding of taxpayers with tax regulations, the more understanding of taxpayers of sanctions will be received if they neglect their tax obligations. Where taxpayers truly understand, they will know administrative sanctions and criminal sanctions in relation to SPT and NPWP.

Based on the explanation of the tendency of respondents 'responses in this study, this study is in line with the findings of Wicaksono, (2016), Nugroho \& Zulaikha, (2012), Setyorini (2016), who found that tax knowledge has a positive and significant effect on tax payers' willingness. Although in other studies not in line with this research is Hardiningsih \& Yulianawati (2011) who found that taxation knowledge does not affect the 
willingness to pay taxes. Based on the explanation above, statistically, tax knowledge is highly correlated and dominant with a very high coefficient of variables among other variables. The results of this study states that statistically this study can answer the problem and hypothesis and research objectives.

\section{Effect of Tax Fiscus Services Against Will to Pay Taxes}

Based on the results of the study it was found that the Tax Fiscksus Service had a positive and significant effect on the willingness to pay taxes at the West Makassar Pratama Tax Office. Simply put, the definition of quality is a dynamic condition related to products, human services, processes, and the environment that meets or exceeds the expectations of those who want it. The results of this study are also related to the findings of the first variable in this study. The composition of taxpayer knowledge is also related to the role of tax officials in this case is AR. how can a Reprentative Account describe rules, provide understanding, motivate taxpayers to supervise, and apply tax penalties to taxpayers. All the elements mentioned are part of the services of the Tax Fiscus in the field. Based on the responses of respondents on the first indicator namely Skiil Competence. This indicator has a very good index and average value category. This shows that taxpayers in West Makassar Primary Tax Office have a willingness to pay taxes because they are supported by AR services, or tax officers who have a broad understanding, insight into service to taxpayers so that taxpayers have the drive and motivation to fulfill their tax obligations. It can also be interpreted that the tax authorities have applied the values of the Ministry of Finance and organizational culture, so that the tax authorities have a thorough understanding of the importance of good service. Research conducted by Jatmiko (2006). Nugroho (2012), Fadhilatunisa, (2020) found that satisfactory AR services for taxpayers will encourage taxpayers' motivation in fulfilling their tax obligations.

The problem of tax fiscal services is reflected in the Ministry of Finance service user satisfaction index which shows that services in the Ministry of Finance in 2017-2018 experienced a significant upward trend. This means that taxpayers are very sensitive to service satisfaction, and this will also provide motivation for priority taxpayers Nur et al., (2020). The next indicator is motivation. This is indeed very important in providing good service to taxpayers. This is related to how to provide strong confidence, change the mindset of voluntary compliance taxpayers. Being a tax motivator is hard work. This is reinforced by the view of Fikriningrum (2012) the ability of the tax authorities to interact well with taxpayers is the basis that the tax authorities must have in serving taxpayers so that it is expected to increase the taxpayer's willingness to pay taxes. Fiskus must have competence, insight, knowledge of the business environment, technical abilities, conceptual abilities, and good social abilities, respondent's response in the Motivation indicator shows a very good average value. This means that the Tax Fiscus at the West Makassar PRATAMA KPP already has very good competency and motivation skills in carrying out their duties so that they are required to pay their taxes.

The next indicator is the service atmosphere in the office, this is related to facilities, work environment ranging from parking problems to the waiting room, and toilets sometimes become elements required by service users. Although the aforementioned elements, are not the responses of respondents, both theoretically and in fact the field is always a reference in assessing the consumer satisfaction index. Based on the explanation above, it can be said that the special tax service at KPP Pratama West Makassar can encourage the willingness to pay taxes, even though the respondent's response in this variable is statistically not as strong as other variables. The results of this study are in tune with Murdiningtyas (2016), that the tax authorities affect the willingness to pay taxes. Setyorini (2016), Nugroho \& Zulaikha, (2012), Wicaksono (2016), who found that fiscal services affect the willingness to pay taxes. Hardiningsih \& Yulianawati (2011) also found that the lack of taxpayers in paying taxes in Jepara. However. Kumala \& Ayu's research (2019) is not in line with this study, because it found that service quality has no significant effect on the willingness to pay taxes. Kumala \& Ayu's research results (2019) for this variable state that the tax apparatus is required to provide friendly, fair, and strict services at all times to taxpayers and can foster public awareness about the responsibility of paying taxes. Taxpayers can recognize taxes from services provided by the tax authorities. For that the tax apparatus must have the skills to be able to satisfy taxpayers. The better the tax authorities, the taxpayers will have a positive attitude towards the taxation process. But if the tax authorities are not good, it will make taxpayers reluctant to pay taxes according to applicable regulations. In this case Doerrenberg \& Peichl (2017) argues that people will tend to participate if there is reciprocity from the government in the form of facilities that are enjoyed publicly. Hallsworth et al., 
(2017), argued that reciprocity in this context means that motivation to comply with taxes depends on perceived service and the quality of the state / government received by citizens in return for their tax payments (this is also related to the concept of conditional cooperation; as stated by Frey and Meier 2004).

Kumala \& Ayu (2019) suggested that the taxpayer's willingness to pay taxes is important in tax collection. The people themselves do not actually like paying taxes. This is because the public has never known the concrete form of rewards from the money spent to pay taxes (Widayati \& Nurlis, 2010). One effort to increase tax revenue is to provide a quality service to taxpayers as customers. With this finding, taxation services are formed by the dimensions of the quality of human resources (HR), tax provisions and tax information systems. Quality standards of world-class service to the taxpayer community will be met if the HR performs their duties in a professional, disciplined and transparent manner. In the condition of taxpayers feeling satisfied with the services provided to him, then they will tend to carry out the obligation to pay taxes in accordance with applicable regulations.

\section{Effect of Tax Examination on Tax Paying Will}

Based on the results of the study, it was found that the Tax Examination had a positive and significant effect on the willingness to pay taxes at the West Makassar Primary Tax Office. Referring to the Attribution Theory which states that when individuals observe someone, they try to determine whether it is caused internally or externally. The response given to an event depends on the individual's interpretation of the event. Taxpayers make an assessment of the tax itself related to compliance with the fulfillment of tax obligations. The better the assessment of tax will raise awareness within the Taxpayer to meet tax obligations in accordance with applicable regulations. Statistically, the tax audit in this study has a very strong correlation with the tax payers' willingness. Based on the tabulation results of respondents' answers showed that all indicators in this examination variable, showed a very good level of responsiveness. This means that the Tax Examination correlates very strongly to the willingness to pay taxes at KPP Pratama Barat Makassar.

Respondents' answers in each indicator show that taxpayers who are willing to pay taxes, for fear of being examined, billed, and suspected of fraud and even tax evasion, or have low compliance. So it can be said that the results of this study can be justified that tax audits are included in one of the factors that encourage the willingness to pay taxes. This research is in line with Research from Alm \& McClellan (2012); Jackson \& Milliron, (1986) show that factors affecting tax compliance include tax audit probability and level of trust, trust in the fairness of government and tax officials, and many cultural and normative factors. Furthermore Torgler, B. (2007), Heryanto et al., (2020) said that many taxpayers who only become tax registrants, but inhibit as obedient taxpayers.

Michael Doran (2009) in his writing Tax Penalties and Tax Compliance argues that, sanctions in the form of penalties or fines, or criminal sanctions are promotions of tax compliance. Penal reform requires an understanding of what motivates taxpayers to pay their taxes. Furthermore Redae \& Sekhon (2016), Togler (2013) taxpayers generally pay their taxes, because they are motivated by external and internal factors. Hanno and Violette (1996) state that the decision to obey or disobey tax rules is a cognitive behavior that is under individual control. In making a tax compliance decision, taxpayers base their attitudes on compliance that develops over time through the acquisition of beliefs about the outcomes (compliance) of compliance and evaluation of those outcomes.

Several studies have shown that increasing the likelihood of high tax audits and fines will increase tax compliance (Witte \& Woodbury 1985; Beck et al. 1991). Tax compliance will decrease if taxpayers perceive tax audits to be small because they believe that they will continue to commit fraud. Based on the responses of respondents regarding tax audits, the results of this study are in line with the research of Sucandra \& Supadmi (2016) who found that tax audits have a positive and significant effect on the willingness to pay taxes. However, this research is not surrendered with research by Monica \& Arisman (2018) who found that tax audits have a negative effect on tax revenue in the 2012-2016 Serang KPP. Similarly, the study of Napitupulu, (2005), which found that the frequency of tax audits had a significant negative effect on audit quality. This study was also not supported by research by De Joman et al., (2020) who found that tax audits had a negative and significant effect on corporate taxpayers compliance in West Denpasar KPP. Kiswanto (2015) also found that the tax audit variable had no effect on tax revenue. Based on the results of this study it can be explained that the factors that 
influence taxpayers in West Makassar Primary Tax Office one of them is due to the Tax Examination, this can be proven by the response of respondents with a very good average on all indicators.

\section{Conclusions}

The results of this study indicate that tax knowledge on taxpayers' willingness to pay is positive and significant. Thus, the problems and research objectives can be met and the first hypothesis in this study can be answered. This shows that if the taxpayer knows the problems related to taxation, it will increase the willingness to pay taxes. Statistical test results show that the coefficient of the tax knowledge variable is highly related and dominant in this study. Quality of service to the willingness to pay taxes has positive and significant effect. Thus, the second problem and hypothesis in this study can be answered. This shows that the quality of service is perceived to have an influence on the willingness of taxpayers to pay their taxes. Tax Examination has a significant positive effect on the willingness to pay taxes. This shows that the third hypothesis in this study which says that the Tax Examination has a significant positive effect is proven and accepted. This means that taxpayers who have been examined or will be examined have a good sensitivity towards their obligation to implement tax regulations. This is also supported by some of the results of the research described earlier. The results of the study propose suggestions to the West Makassar KPP in order to increase the incentive to provide taxation understanding and knowledge to taxpayers. providing satisfactory services can be increased so that taxpayers are encouraged to meet their obligations to pay taxes in accordance with the provisions. It is recommended to the West Makassar Primary Tax Office more intensely to carry out monitoring and inspection with the aim to increase taxpayer awareness.

\section{References}

Akdede, S. H., Salur, S., Kitapcı, İ., Çevik, S., Kılıç, R., Türgay, T., ... \& Geyik, O. (2016). Political Economy of Taxation. IJOPEC Publication.

Allingham, M. G., \& Sandmo, A. (1972). Income tax evasion: A theoretical analysis. Journal of public economics, 1(3-4), 323-338.

Alm, J., \& McClellan, C. (2012). Tax morale and tax compliance from the firm's perspective. Kyklos, 65(1), 1-17.

Amran, A. (2018). Pengaruh Sanksi Perpajakan, Tingkat Pendapatan dan Kesadaran Wajib Pajak terhadap Kepatuhan Wajib Pajak Orang Pribadi. ATESTASI: Jurnal Ilmiah Akuntansi, 1(1), 1-15.

Asrul, A., Lannai, D., \& Ahmad, H. (2018). Analisis Faktor-Faktor Yang Mempengaruhi Manajemen Perusahaan Mengikuti Tax Amnesty. PARADOKS: Jurnal Ilmu Ekonomi, 1(1), 132-151.

Beck, P. J., Davis, J. S., \& Jung, W. O. (1991). Experimental evidence on taxpayer reporting under uncertainty. Accounting Review, 535-558.

De Joman, J. M. C., Sastri, I. I. M., \& Datrini, L. K. (2020). Pengaruh Biaya Kepatuhan, Pemeriksaan Pajak dan Penerapan E-SPT Terhadap Kepatuhan Wajib Pajak Badan pada KPP Pratama Denpasar Barat. Jurnal Riset Akuntansi Warmadewa, 1(1), 50-54.

Devano, S., \& Rahayu, S. K. (2006). Perpajakan: konsep, teori dan isu. Jakarta: Kencana.

Doerrenberg, P., \& Peichl, A. (2018). Tax morale and the role of social norms and reciprocity. evidence from a randomized survey experiment.

Doerrenberg, P., \& Peichl, A. (2018). Tax morale and the role of social norms and reciprocity. evidence from a randomized survey experiment.

Doran, M. (2009). Tax penalties and tax compliance. Harv. J. on Legis., 46, 111.

Dwenger, N., Kleven, H., Rasul, I., \& Rincke, J. (2016). Extrinsic and intrinsic motivations for tax compliance: Evidence from a field experiment in Germany. American Economic Journal: Economic Policy, 8(3), 203-32.

Elster, J. (1989). Social norms and economic theory. Journal of economic perspectives, 3(4), 99-117.

Fadhilatunisa, D. (2020). The Importance of Account Representative Services and Tax Law Enforcement. ATESTASI: Jurnal Ilmiah Akuntansi, 3(1), 74-83.

Fidiana, F. (2018). Kepatuhan Pajak dalam Perspektif Neo Ashabiyah. EKUITAS (Jurnal Ekonomi dan Keuangan), 19(2), 260-275. Fidiana, F. (2018). Kepatuhan Pajak dalam Perspektif Neo Ashabiyah. EKUITAS (Jurnal 
Ekonomi dan Keuangan), 19(2), 260-275.

Fikriningrum, W. K., \& Syafruddin, M. (2012). Analisis Faktor-Faktor Yang Mempengaruhi Wajib Pajak Orang Pribadi Dalam Memenuhi Kewajiban Membayar Pajak (Studi Kasus Pada Kantor Pelayanan Pajak Pratama Semarang Candisari) (Doctoral dissertation, Fakultas Ekonomika dan Bisnis).

Frey, M. (1999). Macht und Moral des Schenkens. Staat und bürgerliche Mäzene vom späten, 18, 12.

Frey, B. S., \& Feld, L. P. (2002). Deterrence and morale in taxation: An empirical analysis.

Frey, B. S., \& Meier, S. (2004). Social comparisons and pro-social behavior: Testing" conditional cooperation" in a field experiment. American Economic Review, 94(5), 1717-1722.

Hallsworth, M., List, J. A., Metcalfe, R. D., \& Vlaev, I. (2017). The behavioralist as tax collector: Using natural field experiments to enhance tax compliance. Journal of public economics, 148, 14-31.

Hamzah, M. F., Ramdani, M. R., \& Muslim, A. H. (2018). Faktor-Faktor Yang Mempengaruhi Kepatuhan Wajib Pajak (Studi Empiris pada KPP Pratama Kabupaten Sidrap). journal of institution and sharia finance, 1(1).

Handayani, S. W., Faturokhman, A., \& Pratiwi, U. (2012). Faktor-faktor yang mempengaruhi kemauan membayar pajak wajib pajak orang pribadi yang melakukan pekerjaan bebas. In Proceeding.

Hanno, D. M., \& Violette, G. R. (1996). An analysis of moral and social influences in tax compliance. Behavioral Research in Accounting, 8, 57-75.

Hardiningsih, P., \& Yulianawati, N. (2011). Faktor-faktor yang mempengaruhi kemauan membayar pajak. Dinamika Keuangan dan Perbankan, 3(1), 126-142.

Heryanto, D., Mursalim, M., \& Lannai, D. (2020). Influences of tax sanctions, taxpayers awareness and social norms on motivation to meet tax obligation. Point of View Research Accounting and Auditing, 1(3), 01-11.

Holler, M., Hoelzl, E., Kirchler, E., Leder, S., \& Mannetti, L. (2008). Framing of information on the use of public finances, regulatory fit of recipients and tax compliance. Journal of Economic Psychology, 29(4), 597-611.

Iqbal, S., \& Sholihin, M. (2019). The role of cognitive moral development in tax compliance decision making. International Journal of Ethics and Systems.

Jackson, B. R., \& Milliron, V. C. (1986). Tax compliance research: Findings, problems, and prospects. Journal of accounting literature, 5(1), 125-165.

Jatmiko, A. N. (2006). Pengaruh Sikap Wajib Pajak pada Pelaksanaan Sanksi Denda, Pelayanan Fiskus dan Kesadaran Perpajakan terhadap Kepatuhan Wajib Pajak (Studi Empiris terhadap Wajib Pajak Orang Pribadi di Kota Semarang) (Doctoral dissertation, Program Pasca Sarjana Universitas Diponegoro).

Keynes, J. M. (1924). Alfred Marshall, 1842-1924. Economic Journal, 34(135), 311-372.

Luttmer, E. F., \& Singhal, M. (2014). Tax morale. Journal of economic perspectives, 28(4), 149-68.

Miniawati, T., Barusman, A. R. P., Rizal, S., \& Cahyadi, D. (2018). Perancangan Teknik Dan Prosedur Pemeriksaan Pajak Atas Harta Wajib Pajak Yang Mengikuti Program Pengampunan Pajak Sesuai Undang-Undang Nomor 11 Tahun 2016. Jurnal Akuntansi dan Keuangan, 9(1), 9.

Monica, T., \& Arisman, A. (2018). Pengaruh Keadilan Pajak, Sistem Perpajakan, Dan Diskriminasi Pajak Terhadap Persepsi Wajib Pajak Orang Pribdai Mengenai Etika Penggelapan Pajak (Tax Evasion)(Studi Empiris Pada Kantor Pelayanan Pajak Pratama Seberang Ulu Kota Palembang).

Monica, R., \& Andi, A. (2019). Pengaruh Kepatuhan Wajib Pajak, Pemeriksaan Pajak, Dan Pencairan Tunggakan Pajak Terhadap Penerimaan Pajak Badan Pada Kantor Pelayanan Pajak Pratama Serang Tahun 2012-2016. Jurnal Riset Akuntansi Terpadu, 12(1).

Murdiningtyas, N. E., \& Adi, S. W. (2016). Faktor-Faktor yang Mempengaruhi Kemauan Membayar Pajak Wajib Pajak Orang Pribadi yang Melakukan Pekerjaan Bebas (Studi Empiris Pada Kantor Pelayanan Pajak Pratama Sukoharjo) (Doctoral dissertation, Universitas Muhammadiyah Surakarta).

Napitupulu, H. S. L. (2005). Pengaruh Frekuensi Pemeriksaan Pajak Dan Kualitas Pemeriksa Pajak Terhadap Tingkat Kepatuhan Wajib Pajak Badan Pada Kantor Wilayah Direktorat Jenderal Pajak Jawa Bagian Timur I Surabaya (Doctoral dissertation, Universitas Airlangga).

Nugroho, R. A., \& Zulaikha, Z. (2012). Faktor-Faktor Yang Mempengaruhi Kemauan Untuk Membayar Pajak Dengan Kesadaran Membayar Pajak Sebagai Variabel Intervening (Studi Kasus Wajib Pajak Orang Pribadi Yang Melakukan Pekerjaan Bebas Yang Terdaftar Di KPP Pratama Semarang Tengah Satu) (Doctoral dissertation, Fakultas Ekonomika dan Bisnis).

Nur, M., Masud, M., \& Mursalim, M. (2020). Determinan Keputusan Rasional Menjadi Wajib Pajak Prioritas. Journal of Accounting and Finance (JAF), 1(1), 17-40.

Ockey, J. (2004). State, bureaucracy and polity in modern Thai politics. Journal of Contemporary Asia, 34(2), 143162. 
Paetzold, J., \& Winner, H. (2016). Taking the high road? Compliance with commuter tax allowances and the role of evasion spillovers. Journal of Public Economics, 143, 1-14.

Pelu, M. F. A., Lannai, D., \& Rianthy, G. A. (2020). Application Benchmark Behavioral Analysis Model in Supervision and Inspection Tax. ATESTASI: Jurnal Ilmiah Akuntansi, 3(1), 50-62.

Prihastanti, R., \& Kiswanto, K. (2015). Tingkat Kepatuhan Wajib Pajak Badan Terhadap Penerimaan Pajak Dimoderasi oleh Pemeriksaan Pajak. Accounting Analysis Journal, 4(1).

Rahayu, S. K. (2010). Indonesian Taxation: Formal Concepts and Aspects. Yogyakarta: Graha Ilmu.

Ratih Kumala, Renisya Ayu (2019). Pengaruh kesadaran membayar pajak, pengetahuan dan pemahaman peraturan perpajakan dan kualitas Layanan terhadap kemauan membayar pajak Wajib orang pribadi di KPP Pratama Bekasi Utara dan Bekasi Selatan. Jurnal eksekutif, 16(2)

Riahi-Belkaoui, A. (2004). Relationship between tax compliance internationally and selected determinants of tax morale. Journal of international accounting, auditing and taxation, 13(2), 135-143.

Redae, R. B., \& Sekhon, S. (2016). Taxpayers' knowledge and tax compliance behavior in Ethiopia: A study of Tigray State. International Journal of Management and Commerce Innovations, 3(2), 1090-1102.

RW, N. S., Bagianto, A., \& Yuniati, Y. (2018). Pengaruh Pemeriksaan Pajak terhadap Kepatuhan Wajib Pajak dan Dampaknya terhadap Efektivitas Penerimaan Pajak Penghasilan Badan. Jurnal Ilmiah MEA (Manajemen, Ekonomi, \& Akuntansi), 2(2), 115-143.

Setyonugroho, H. (2012). Faktor-Faktor yang Mempengaruhi Kemauan Untuk Membayar Pajak Pada Wajib Pajak Orang Pribadi di KPP Pratama Surabaya Tegalsari (Doctoral dissertation, STIE PERBANAS SURABAYA).

Setyorini, C. T. (2016). The influence of tax knowledge, managerial benefit and tax socialization toward taxpayer's willingness to pay SME’s tax. Acta Universitatis Danubius. Economica, 12(5), 96-107.

Sucandra, L. K. I. P., \& Supadmi, N. L. (2016). Pengaruh kualitas pelayanan, pemeriksaan pajak, pengetahuan perpajakan dan sanksi perpajakan pada kepatuhan wajib pajak restoran. E-Jurnal Akuntansi Universitas Udayana, 16(2), 1210-1237.

Sugiyono, P. D. (2010). Metode penelitian pendidikan. Pendekatan Kuantitatif.

Supadmi, N. L. (2009). Meningkatkan kepatuhan wajib pajak melalui kualitas pelayanan. Jurnal Ilmiah Akuntansi Dan Bisnis, 4(2), 1-14.

Susyanti, J., \& Dahlan, A. (2016). Perpajakan untuk Akademisi dan Praktisi. Malang: Penerbit: Empat Dua Media.

Su'un, M., \& Ahmad, H. (2020). Influences of variable Anteseden functional Integrity Examiner on quality tax inspection. Point of View Research Accounting and Auditing, 1(3), 12-24.

Torgler, B. (2007). Tax compliance and tax morale: A theoretical and empirical analysis. Edward Elgar Publishing.

Torgler, B. (2013). A field experiment in moral suasion and tax compliance focusing on underdeclaration and overdeduction. FinanzArchiv/Public Finance Analysis, 393-411.

Utami, S. R., \& Soerono, A. N. (2012). Pengaruh Faktor-Faktor Eksternal Terhadap Tingkat Kepatuhan Wajib Pajak Di Lingkungan Kantor Pelayanan Pajak Pratama Serang. E-Jurnal Akuntansi Universitas Udayana.

Wicaksono, R. (2016). Faktor-Faktor Yang Mempengaruhi Kepatuhan Wajib Pajak Usaha Mikro Kecil Dan Menengah (UMKM) Dalam Membayar Pajak Sesuai PP No. 46 Tahun 2013 Pada UMKM Di Kabupaten Bantul. Fokus Bisnis: Media Pengkajian Manajemen dan Akuntansi, 15(2), 1-21.

Widayati, N., \& Nurlis, A. (2010). Faktor-faktor Yang Mempengaruhi Kemauan Membayar Pajak Wajib Pajak Orang Pribadi Yang Melakukan Pekerjaan Bebas (Studi kasus pada KPP Pratama Gambir Tiga). Makalah Simposium Nasional Perpajakan XIII (yang dipresentasikan pada tahun 2010).

Winarsih, E. (2018). Pengaruh Sistem Perpajakan, Kualitas Pelayanan dan Terdeteksinya Kecurangan Terhadap Penggelapan Pajak (Studi Pada Kantor Pelayanan Pajak Pratama Makassar Selatan). ATESTASI: Jurnal Ilmiah Akuntansi, 1(1), 55-69.

Witono, B. (2008). Peranan pengetahuan pajak pada kepatuhan wajib pajak.

Witte, A. D., \& Woodbury, D. F. (1985). The effect of tax laws and tax administration on tax compliance: The case of the US individual income tax. National Tax Journal, 1-13 